\title{
FAKTOR-FAKTOR YANG MEMENGARUHI NILAI PERUSAHAAN DENGAN PROFITABILITAS SEBAGAI VARIABEL MEDIASI PADA SEKTOR PERTAMBANGAN DI BEI TAHUN 2015-2018
}

\author{
Emi Mei Astutik \\ Universitas Negeri Surabaya \\ emiastutik16080574114@mhs.unesa.ac.id
}

\begin{abstract}
The purpose of this study is to determine the effect of corporate social responsibility, dividend policy, company age, independent board of commissioners, and managerial ownership with profitability as a mediating variable. The population used is mining sector companies listed on the Indonesia Stock Exchange (BEI) in 2015-2018. By using purposive sampling, the sample is ten companies. This study using path analysis and processed with IBM SPSS 25. This study's results are only corporate social responsibility, dividend policy, and profitability that affect firm value.Meanwhile, variable company age, independent board of commissioners, and managerial ownership do not affect firm value. Investors are not interested in old companies because they cannot adapt to existing developments. Investors are also not interested in investing in companies that have agency problems. The variables that influence profitability are corporate social responsibility and independent board of commissioners. Meanwhile, dividend policy, company age, and managerial ownership cannot affect profitability. There are characteristics of some investors who do not like the distribution of dividends. Investors prefer newly established companies because they are more innovative in their business. Agency problems are also a factor that hinders investors from investing in companies. This study shows that profitability cannot be a mediating variable in this study because high profitability cannot determine high firm value.
\end{abstract}

Keywords: company age; company value; corporate social responsibility; dividend policy; profitability.

\section{PENDAHULUAN}

Sebuah perusahaan memiliki tujuan utama yaitu mengendalikan dan mengelola sumber daya yang dimiliki dengan memaksimalkan kemampuannya untuk mendapatkan laba yang maksimal. Karena elemen yang penting untuk menciptakan nilai perusahaan adalah laba perusahaan. Bagi investor, indikator yang penting dalam memahami keberhasilan perusahaan adalah nilai perusahaan. Adanya peningkatan pada nilai perusahaan menjadikan investor percaya pada kinerja perusahaan dan prospeknya di masa mendatang (Rudangga \& Sudiarta, 2016).

Besarnya nilai perusahaan diukur menggunakan salah satu rasio penilaian yaitu earning per share (Harmono, 2017). Dalam satu periode pelaporan keuangan, laba dapat diciptakan melalui kemampuan setiap lembar saham yang disebut Earning Per Share (EPS). Terdapat tiga alasan yang mendasari penggunaan dan komponen tersebut. Pertama, karena suatu saham dapat diestimasi nilai intrinsiknya menggunakan EPS. Kedua, perusahaan menggunakan earning untuk membayarkan dividen. Ketiga, perubahan earning memiliki hubungan dengan perubahan harga saham (Tandelilin, 2010).

Peningkatan EPS menjadi salah satu faktor investor untuk membeli saham, karena kinerja perusahaan tersebut dinilai baik oleh investor. EPS yang tinggi menunjukkan kemampuan dan keberhasilan perusahaan dalam meningkatkan kesejahteraan bagi investor. Jika EPS perusahaan tinggi, maka uang yang dimiliki perusahaan lebih banyak untuk diinvestasikan kembali dalam bisnis atau membagikannya kepada investor dalam bentuk dividen. Dengan demikian para investor akan memiliki ketertarikan yang tinggi dalam berinvestasi. Suatu perusahaan yang memiliki jumlah investor yang tinggi mengindikasikan bahwa nilai perusahaan tersebut tinggi (Adi et al., 2013).

Berdasarkan grafik pergerakan EPS perusahaan per sektor yang terdaftar di BEI tahun 2015-2018. Terdapat sembilan sektor yang terdaftar di BEI dan terlihat bahwa sektor mining mengalami kenaikan setiap tahunnya dari tahun 2015 apabila dibandingkan dengan sektor lainnya yang mengalami pergerakan fluktuatif. Seperti yang terlihat dalam grafik bahwa sektor mining untuk tahun 2015 
menunjukkan EPS sebesar Rp2.8181, tahun 2016 mengalami kenaikan yang berada pada angka Rp156.464, kemudian tahun 2017 meningkat lagi sebesar Rp235.561, dan pada tahun 2018 tetap meningkat sebesar Rp251.325. Namun, kenaikan EPS tersebut bertolak belakang dengan harga saham sektor pertambangan yang mengalami penurunan pada tahun 2015. Hal tersebut dikarenakan oleh adanya perlambatan ekonomi pada beberapa negara tujuan ekspor batu bara seperti Tiongkok, yang menyebabkan permintaan menurun dikarenakan harga batu bara yang cenderung belum kembali normal (Tribun News, 2015).

Menurut Utomo (2016), nilai perusahaan mampu dipengaruhi variabel tanggung jawab sosial perusahaan. Pengungkapan kegiatan tanggung jawab sosial pada laporan tahunan dapat meningkatkan citra perusahaan. Karena investor menilai bahwa perusahaan memerhatikan tanggung jawabnya terhadap lingkungan dan masyarakat di samping kepentingan untuk mencari keuntungan (Bidhari et al., 2013). Sedangkan, Mukhtaruddin et al. (2014) menjelaskan bahwa nilai perusahaan tidak berpengaruh dengan tanggung jawab sosial perusahaan.

Menurut Suryaningsih et al. (2018) nilai perusahaan dapat dipengaruhi faktor lain yaitu kebijakan dividen. Karena nilai perusahaan yang meningkat disebabkan oleh pembayaran dividen yang tinggi (Rizqia et al. (2013). Penelitian Pascareno \& Siringoringo (2016) menunjukkan hasil yang berbeda bahwa kebijakan dividen tidak mampu memengaruhi nilai perusahaan.

Susanti \& Restiana (2018) menyatakan bahwa variabel umur perusahaan menjadi salah satu faktor pengaruh nilai perusahaan. Informasi mengenai perusahaan dapat diberikan lebih banyak saat perusahaan telah lama berdiri, dan hal itu akan menumbuhkan kepercayaan investor terhadap perusahaan. Namun Sucuahi \& Cambarihan (2016) menunjukkan hasil bahwa nilai perusahaan tidak mempunyai pengaruh dengan umur perusahaan.

Suryaningsih et al. (2018) menambahkan faktor lain sebagai pengaruh nilai perusahaan ialah dewan komisaris independen. Dewi \& Nugrahanti (2017) menjelaskan adanya pengawasan yang efektif dari dewan komisaris independen terhadap manajemen dapat mengurangi tindakan kecurangan dalam pelaporan keuangan yang dilakukan manajemen. Sedangkan menurut Rachmania (2017), nilai perusahaan tidak berpengaruh dengan dewan komisaris independen.

Suryaningsih et al. (2018) menyatakan bahwa kepemilikan manajerial memengaruhi nilai perusahaan. Kepemilikan saham oleh manajemen dipercaya mampu menekan terjadinya masalah keagenan. Berbeda dengan penelitian Luthfiah \& Suherman (2018) yang membuktikan bahwa kepemilikan manajerial tidak berpengaruh pada nilai perusahaan.

Nilai perusahaan juga dapat dipengaruhi oleh profitabilitas (Utomo 2016). Sedangkan penelitian lain menyebutkan profitabilitas yang meningkat berdampak pada peningkatan laba per lembar saham. Apabila peningkatan laba per lembar saham tidak diiringi dengan meningkatnya harga saham, menjadikan nilai perusahaan menurun (Pascareno \& Siringoringo, 2016).

Rosdwianti et al. (2016) menjelaskan bahwa tanggung jawab sosial suatu perusahaan menjadi salah satu cara dalam meningkatkan laba. Dalam mencapai tujuan utamanya, tanggung jawab sosial perusahaan diharapkan mampu mencari laba dan tetap menjaga kelestarian lingkungan. Sedangkan Christine \& Ekasari (2012) menyebutkan bahwa profitabilitas tidak dapat dipengaruhi oleh tanggung jawab sosial perusahaan.

Menurut Purnama (2018), kebijakan dividen memberikan pengaruh terhadap profitabilitas. Sedangkan, Henny (2017) mengemukakan bahwa profitabilitas berpengaruh dengan kebijakan dividen. Apabila perusahaan setiap tahunnya menetapkan kebijakan pembagian dividen, maka menjadi pengurang bagi keuntungan perusahaan yang akan digunakan untuk biaya operasional tahun berikutnya dan hal itu dapat mengurangi keuntungan perusahaan. 
Emi Mei Astutik, Faktor-Faktor yang Memengaruhi Nilai Perusahaan dengan Profitabilitas sebagai Variabel Mediasi pada Sektor Pertambangan di BEI tahun 2015-2018

Penelitian Wibisana et al. (2018) menunjukkan pengaruh positif umur perusahaan terhadap profitabilitas. Sedangkan penelitian Arisadi et al. (2013), profitabilitas tidak dapat dipengaruhi oleh umur perusahaan, karena perusahaan yang berumur lama lebih cenderung memiliki banyak pengalaman tidak dapat memengaruhi tinggi rendahnya profitabilitas perusahaan.

Islami (2018) menyatakan bahwa dewan komisaris independen dapat memengaruhi profitabilitas. Karena fungsi pengawasan dalam pengelolaan perusahaan dapat ditingkatkan dengan dewan komisaris independen. Sedangkan Raja (2016) mengemukakan bahwa profitabilitas tidak berpengaruh dengan dewan komisaris independen.

Ramiyati (2016) menjelaskan bahwa faktor penting untuk mencapai profitabilitas perusahaan ialah kepemilikan manajerial. Sedangkan Kusumandari (2016) menunjukkan hasil bahwa profitabilitas tidak dapat dipengaruhi kepemilikan manajerial, karena dengan jumlah kepemilikan manajerial yang rendah menjadikan manajer tidak berusaha untuk meningkatkan kinerja perusahaannya. Hal itu disebabkan jumlah laba yang diperoleh melalui saham yang dimilikinya akan tetap sedikit karena proporsi kepemilikannya yang juga sedikit.

Profitabilitas bisa menjadi variabel mediasi karena tujuan utama perusahaan adalah kemakmuran pemegang saham bukan profitabilitas (Andrian 2012). Indikasi kemakmuran pemegang saham dapat dilihat dari bagaimana perusahaan mampu berkembang dengan memberikan nilai tambah bagi perusahaan.

Penelitian ini bertujuan untuk menganalisis pengaruh tanggung jawab sosial perusahaan, kebijakan dividen, umur suatu perusahaan, dewan komisaris independen, dan kepemilikan manajerial terhadap nilai perusahaan dan mengetahui pengaruh profitabilitas sebagai variabel mediasi pada sektor pertambangan di BEI tahun 2015-2018.

\section{KAJIAN PUSTAKA DAN PENGEMBANGAN HIPOTESIS}

\section{Stakeholder Theory}

Stakeholder theory adalah teori yang menjelaskan pihak mana saja yang berhak atas tanggung jawab dari perusahaan. Stakeholder yang dimaksud merupakan pihak yang memiliki kepentingan baik secara langsung ataupun tidak langsung pada suatu perusahaan. Perusahaan harus membangun dan mempertahankan hubungan baik dengan para stakeholder. Stakeholder theory menjelaskan hubungan tanggung jawab sosial perusahaan pada nilai perusahaan dan profitabilitas (Christine \& Ekasari, 2012).

\section{Signalling Theory}

Signalling theory yang dikemukakan oleh Brigham dan Houston (2014), teori ini menjelaskan tentang bagaimana suatu perusahaan dalam mengambil tindakan untuk menyampaikan informasi kepada investor terkait sudut pandang manajemen terhadap prospek perusahaan di masa mendatang. Dari informasi yang diperoleh para investor akan dimanfaatkan untuk mengambil keputusan dalam berinvestasi (Sudana, 2011). Signalling theory menjelaskan hubungan antara usia perusahaan dan profitabilitas terhadap nilai perusahaan serta usia perusahaan terhadap profitabilitas (Yumiasih \& Isbanah, 2017).

\section{Bird in the Hand Theory}

Birt in the hand theory adalah pengembangan teori oleh Myron Gordon dan John Lintner pada tahun1962-1963. Gordon dan Lintner (1962-1963) berpendapat harga saham perusahaan akan tinggi jika pembagian dividennya juga tinggi. Investor lebih memilih pembagian dividem saat ini, karena memiliki risiko lebih kecil dibandingkan pembagian dividen di masa mendatang dengan risiko adanya ketidakpastian arus kas perusahaan (Sudana, 2011). Bird in the hand theory menjelaskan hubungan antara kebijakan dividen pada nilai perusahaan dan profitabilitas (Purnama, 2018). 


\section{Agency Theory}

Menurut Sudana (2011:11), agency theory menjelaskan tentang hubungan antara manajemen dan pemegang saham. Masalah keagenan ditimbulkan akibat tujuan yang berbeda antara manajemen dengan pemegang saham. Di mana pemegang saham lebih mengutamakan besarnya dividen yang diperoleh, sedangkan pihak manajemen lebih mengutamakan keberlangsungan hidup perusahaan. Agency theory menjelaskan hubungan dewan komisaris independen dan kepemilikan manajerial terhadap nilai perusahaan dan profitabilitas (Putra, 2015).

\section{Nilai Perusahaan (Y)}

Nilai perusahaan adalah suatu indikator bagi investor untuk mengevaluasi pasar suatu perusahaan secara keseluruhan (Zuhroh, 2019). Menurut Siahaan (2013), nilai perusahaan ialah nilai jual suatu perusahaan atau nilai tambah bagi pemegang saham. Harga saham dapat mencerminkan nilai dari suatu perusahaan, sehingga nilai pasar dapat diartikan sebagai nilai perusahaan. Indikator nilai perusahaan pada penelitian ini menggunakan rasio EPS perusahaan, dapat dilihat di rumus (1).

EPS $=\frac{\text { Laba setelah pajak }}{\text { Jumlah lembar saham beredar }}$

\section{Tanggung Jawab Sosial Perusahaan (X1)}

Sudana (2011) menyatakan bahwa tanggung jawab sosial merupakan sebuah kebijakan bagi perusahaan berupa kontribusi terhadap masyarakat dan lingkungan. Kontribusi perusahaan terhadap masyarakat dapat diwujudkan dengan melakukan pembangunan yang berkelanjutan berdasarkan kesepakatan dari para pemangku kepentingan sesuai hukum yang berlaku serta norma perilaku internasional. Variabel pengungkapan tanggung jawab sosial perusahaan diukur dengan Calculation of CSR Disclosude Index (CSRDI), dapat dilihat di rumus (2).

$\operatorname{CSRDI}=\frac{\mathrm{Xi}}{\mathrm{N}}$

\section{Kebijakan Dividen (X2)}

Kebijakan dividen merupakan kebijakan terkait laba perusahaan yang akan dibagikan pada pemegang saham sebagai dividen atau menahannya sebagai laba ditahan untuk investasi di masa mendatang (Sudana, 2011). Apabila perusahaan menetapkan kebijakan untuk membagikan dividen, maka akan menjadi pengurang laba ditahan yang mengakibatkan total sumber dana internal menjadi berkurang (Purnama, 2018). Indikator kebijakan dividen menggunakan Dividend Payout Ratio (DPR), dapat dilihat di rumus (3).

DPR $=\frac{\text { Dividen per share }}{\text { Earning per share }} \times 100 \%$

\section{Umur Perusahaan (X3)}

Umur perusahaan diartikan sebagai seberapa lamanya sebuah perusahaan berkembang, bertahan, dan berdiri (Susanti \& Restiana, 2018). Dari didirikannya perusahaan yang berdasarkan pada akta pendirian hingga penelitian ini dilakukan merupakan cara untuk menghitung umur Perusahaan. Semakin bertambahnya umur perusahaan, maka kinerja perusahaan yang dihasilkan akan semakin baik (Yumiasih \& Isbanah, 2017). Perhitungan variabel umur perusahaan dapat dilihat di rumus (4).

Umur perusahaan $=\log \mathrm{n}$ umur perusahaan.

\section{Dewan Komisaris Independen (X4)}

Dewan komisaris independen adalah anggota komisaris yang tidak memiliki keterikatan bisnis atau keluarga dengan pihak yang berkepentingan terhadap perusahaan, sehingga bekerja hanya untuk melindungi kepentingan pemegang saham (Raja, 2016). Dewan independen berfungsi sebagai peningkatan peran dewan komisaris untuk menciptakan suatu tata kelola perusahaan secara baik (Siahaan, 2013). Perhitungan jumah dewan komisaris independen dapat dilihat di rumus (5). 
Emi Mei Astutik, Faktor-Faktor yang Memengaruhi Nilai Perusahaan dengan Profitabilitas sebagai Variabel Mediasi pada Sektor Pertambangan di BEI tahun 2015-2018

Komisaris independen $=\frac{\text { Jumlah anggota komisaris independen }}{\text { Jumlah anggota dewan komisaris }} \times 100 \%$

\section{Kepemilikan Manajerial (X5)}

Kepemilikan manajerial adalah pihak manajemen sekaligus pemegang saham sehingga berperan aktif dalam pengambilan keputusan perusahaan (Nurwahidah, Husnan, \& AP, 2019). Salah satu manfaat dari kepemilikan manajerial adalah untuk menyeimbangkan antara kepentingan manajemen dengan pemegang saham, sehingga konsekuensi dari pengambilan keputusan dapat ditanggung oleh kedua belah pihak secara adil (Mukhtaruddin et al., 2014). Perhitungan kepemilikan manajerial dapat dilihat di rumus (6).

Kepemilikan Manajerial $=\frac{\sum \text { Kepemilikan saham manajemen }}{\sum \text { Lembar saham yang beredar }} \times 100 \%$

\section{Profitabilitas (Z)}

Profitabilitas merupakan kemampuan perusahaan untuk menghasilkan laba melalui sumber daya yang dimiliki oleh perusahaan (Sudana, 2011). Profitabilitas berguna bagi pemilik perusahaan dalam melakukan tolak ukur keberhasilan perusahaan yang dipimpin. Profitabilitas diproksikan menggunakan Return on Assets (ROA).

$\mathrm{ROA}=\frac{\text { Earning after taxes }}{\text { Total } \text { assets }} \times 100 \%$

\section{Hubungan antar Variabel}

Menurut Mukhtaruddin et al. (2019), tanggung jawab sosial perusahaan memiliki pengaruh terhadap nilai perusahaan. Sesuai dengan stakeholder theory bahwa perusahaan harus berkontribusi pada masyarakat dan memberi manfaat kepada stakeholdernya, karena kehadiran perusahaan sangat dipengaruhi oleh para stakeholder. Selain itu, pengungkapan tanggung jawab sosial perusahaan dalam laporan tahunan dapat memperkuat citra perusahaan dan menjadi salah satu pertimbangan yang diperhatikan oleh investor untuk berinvestasi. Sejalan dengan penelitian Rachmania (2017) dan Bidhari et al. (2013) menunjukkan bahwa perusahaan yang bernilai adalah perusahaan yang memerhatikan tanggung jawab pada lingkungan sekitar atas dampak kegiatan operasional perusahaan.

H1: Tanggung jawab sosial perusahaan mampu memengaruhi nilai perusahaan.

Penelitian Rizqia et al. (2013) menunjukkan bahwa kebijakan dividen berpengaruh terhadap nilai perusahaan. Hal tersebut sesuai dengan bird in the hand theory yang menyatakan investor lebih menyukai pembagian dividen daripada capital gain dengan alasan risikonya yang lebih kecil. Sehingga investor lebih memercayakan dananya untuk berinvestasi pada perusahaan yang membagikan labanya dalam bentuk dividen secara konsisten. Peningkatan jumlah investor dalam perusahaan menjadikan harga saham cenderung tinggi yang mencerminkan nilai perusahaan tinggi. Hasil penelitian oleh Rahayu \& Asandimitra (2014), Hakim (2018) menunjukkan kebijakan dividen memiliki pengaruh dengan nilai perusahaan.

H2: Kebijakan dividen mampu memengaruhi nilai perusahaan.

Berdasarkan signalling theory, perusahaan yang berumur lama dapat menimbulkan sinyal positif bagi investor, karena cenderung lebih mapan. Selain itu, perusahaan yang berumur lama lebih dikenal dan diakui oleh masyarakat serta memiliki berbagai macam pembelajaran mengenai industri yang sama maupun berbeda. Pengalaman dalam mengelola perusahaan memengaruhi keuntungan perusahaan yang akan berdampak pada nilai perusahaan (Yumiasih \& Isbanah, 2017). Penelitian oleh Susanti \& Restiana (2018) menyebutkan bahwa umur perusahaan memberikan pengaruh signifikan pada nilai perusahaan.

H3: Umur perusahaan mampu memengaruhi nilai perusahaan. 
Berdasarkan agency theory, dewan komisaris independen dapat bertindak sebagai penengah dalam perselisihan untuk meminimalisir masalah keagenan, karena komisaris independen tidak memiliki hubungan apapun dengan manajemen maupun investor. Komisaris independen juga dapat memberikan pengawasan secara objektif dalam mendukung kinerja perusahaan. Pengawasan tersebut menyebabkan kualitas dari pelaporan keuangan menjadi lebih baik dan hal itu berdampak pada modal yang akan ditanamkan oleh investor, sehingga mengakibatkan peningkatan harga saham perusahaan (Dewi \& Nugrahanti, 2017). Hasil penelitian Putra (2015) dan Suryaningsih et al. (2018) menunjukkan proporsi dewan komisaris independen memengaruhi nilai perusahaan.

H4: Dewan komisaris independen mampu memengaruhi nilai perusahaan.

Teori keagenan menjadi dasar pengaruh antara kepemilikan manajerial dengan nilai perusahaan. Masalah keagenan akan menghambat perusahaan dalam memaksimalkan nilai perusahaan. Adanya kepemilikan manajerial dipandang dapat mengurangi konflik keagenan. Manajemen dapat meningkatkan kepemilikan saham sehingga dapat mengurangi biaya agensi, karena peran kepemilikan saham manajemen mampu menyatukan kepentingan antara manajemen dengan pemegang saham (Mukhtaruddin et al., 2014). Rizqia et al. (2013) menyatakan nilai perusahaan dapat dipengaruhi oleh kepemilikan manajerial.

H5: Kepemilikan manajerial mampu memengaruhi nilai perusahaan.

Berdasarkan signalling theory, investor akan mendapatkan sinyal positif terkait dengan kinerja perusahaan dalam meningkatkan laba. Hal tersebut menimbulkan sentimen positif untuk investor dalam permintaan saham (Rizqia et al., 2013). Zuhroh (2019) menyatakan bahwa laba yang tinggi mengindikasikan bahwa perusahaan mampu membayar dividen yang tinggi pula, sehingga profitabilitas tinggi dapat dihasilkan oleh perusahaan dan akan menarik investor untuk melakukan investasi. Hal itu sejalan dengan penelitian Bidhari et al. (2013); Luthfiah \& Suherman, (2018).

H6: Profitabilitas mampu memengaruhi nilai perusahaan.

Menurut Christine \& Ekasari (2012), tanggung jawab sosial perusahaan memiliki pengaruh terhadap nilai perusahaan. Sejalan dengan stakeholder theory yang menjelaskan kesadaran perusahaan akan dampak yang terjadi akibat dari kegiatan operasional perusahaan sehingga timbul program tanggung jawab sosial terhadap stakeholder. Program tersebut menjadikan citra perusahaan semakin baik. Investor lebih tertarik pada perusahaan dengan citra yang baik karena menjadikan konsumen semakin loyal. Penjualan perusahaan yang stabil terjadi karena meningkatnya loyalitas konsumen dan diharapkan juga adanya peningkatan pada profitabilitas perusahaan. Hasil penelitian Rosdwianti et al. (2016) membuktikan jika tanggung jawab sosial perusahaan memberikan pengaruh pada profitabilitas.

H7: Tanggung jawab sosial perusahaan mampu memengaruhi profitabilitas.

Mengacu pada bird in the hand theory, pembayaran dividen dianggap lebih menarik perhatian investor daripada capital gain. Semakin tinggi dividen, akan semakin tinggi ketertarikan investor untuk berinvestasi di perusahaan tersebut. Hal tersebut menjadikan perusahaan memiliki aliran modal yang tinggi untuk menghasilkan laba perusahaan (Henny, 2017). Purnama (2018) menyebutkan bahwa kebijakan dividen berpengaruh signifikan pada profitabilitas.

H8: Kebijakan dividen mampu memengaruhi profitabilitas.

Profitabilitas yang tinggi cenderung dimiliki oleh perusahaan yang berumur lama, karena perusahaan telah mempunyai nama atau sudah dikenal di masyarakat sehingga tingkat penjualan lebih stabil. Hal tersebut menimbulkan ketertarikan investor untuk berinvestasi yang mana sangat membantu perusahaan dalam meningkatkan kapasitas dalam beroperasi. Sesuai dengan signalling theory, perusahaan yang berumur lama memiliki lebih banyak pengalaman dalam berbisnis sehingga 
Emi Mei Astutik, Faktor-Faktor yang Memengaruhi Nilai Perusahaan dengan Profitabilitas sebagai Variabel Mediasi pada Sektor Pertambangan di BEI tahun 2015-2018

menimbulkan sentimen positif bagi investor (Wibisana et al., 2018). Susanti \& Restiana (2018) membuktikan bahwa umur perusahaan dapat memengaruhi profitabilitas perusahaan.

H9: Umur perusahaan mampu memengaruhi profitabilitas.

Agency theory menjelaskan ukuran dewan komisaris independen dapat mengatasi masalah keagenan karena fungsi pengawasan dan pengendalian internal (Ramiyati, 2016). Berdasarkan fungsi tersebut serta peranan yang obyektif atau tidak terikat oleh kepentingan dan pihak manapun, menjadikan manajemen akan selalu bertindak sesuai tujuan perusahaan yaitu menghasilkan keuntungan yang maksimal. Sehingga ukuran dewan komisaris independen yang tepat dapat meningkatkan profitabilitas perusahaan (Putra, 2015). Pada penelitian Islami (2018) dewan komisaris independen berpengaruh terhadap profitabilitas.

H10: Dewan komisaris independen mampu memengaruhi profitabilitas.

Berdasarkan teori keagenan, perbedaan kepentingan antara manajer dan investor dapat menimbulkan masalah keagenan. Hal tersebut dapat diatasi dengan kepemilikan manajerial, karena akan mendorong penyatuan kepentingan sehingga manajer bertindak sesuai dengan keinginan investor yaitu meningkatkan laba perusahaan (Ramiyati, 2016). Semakin tinggi jumlah kepemilikan saham manajemen, maka semakin meningkat profitabilitas perusahaan (Kusumandari, 2016). Ramiyati (2016) menunjukkan bahwa proporsi kepemilikan saham manajemen memengaruhi profitabilitas perusahaan.

H11: Kepemilikan manajerial mampu memengaruhi profitabilitas.

Zulaikhah (2018) dalam penelitiannya mengemukakan bahwa profitabilitas mampu memediasi tanggung jawab sosial perusahaan terhadap nilai perusahaan. Kinerja keuangan suatu perusahaan akan meningkat dengan adanya peran kegiatan tanggung jawab sosial perusahaan, karena modal milik investor cenderung akan dipercayakan pada perusahaan yang telah memberikan informasi mengenai tanggung jawab sosialnya. Perilaku etis perusahaan tersebut berdampak positif yang dalam jangka panjang tercermin pada peningkatan keuntungan dan nilai perusahaan.

H12: Profitabilitas memediasi tanggung jawab sosial perusahaan terhadap nilai perusahaan.

Menurut Pratiwi (2018), ada beberapa investor yang memilih tidak menerima dividen karena dividen dianggap bertarif pajak yang lebih tinggi dibanding capital gain. Investor lebih menyukai saat jumlah dividen tidak dibagikan dan diinvestasikan kembali ke perusahaan dan mengendap di dalam saldo laba. Dengan demikian, perusahaan dapat memaksimalkan kegiatan operasionalnya karena perusahaan memiliki nilai kas yang tinggi. Nilai perusahaan dapat meningkat karena para investor tertarik untuk melakukan investasi dengan alasan sinyal baik yang diberikan oleh profitabilitas perusahaan. Menurut Hakim (2018), profitabilitas mampu memediasi kebijakan dividen dengan nilai perusahaan.

H13: Profitabilitas memediasi kebijakan dividen terhadap nilai perusahaan.

Ulfa (2017) menyatakan bahwa profitabilitas memberikan pengaruh mediasi antara umur perusahaan terhadap nilai perusahaan. Perusahaan yang berumur lama cenderung paling banyak dalam mengungkapkan aktivitas perusahaan dan rasa kepercayaan investor dalam menanamkan modalnya lebih tinggi, karena diasumsikan perusahaan mampu bertahan dan menghasilkan laba yang tinggi dengan banyaknya aset yang dimiliki. Dengan demikian permintaan saham perusahaan menjadi tinggi.

H14: Profitabilitas memediasi umur perusahaan terhadap nilai perusahaan. 
Penelitian Ulfa (2017) menyatakan bahwa profitabilitas mampu memediasi pengaruh antara dewan komisaris independen dan nilai perusahaan. Dewan komisaris independen bertanggungjawab dan memastikan agar perusahaan berjalan baik. Independensi semakin tinggi jika jumlah dewan komisaris independen semakin banyak, sehingga pengelolaan manajemen yang berkaitan dengan profitabilitas pengawasannya lebih obyektif. Peningkatan profitabilitas perusahaan diikuti dengan peningkatan permintaan saham oleh investor, sehingga harga saham perusahaan meningkat.

H15: Profitabilitas memediasi dewan komisaris independen terhadap nilai perusahaan.

Hasil penelitian Ulfa (2017), profitabilitas mampu memediasi kepemilikan manajerial terhadap nilai perusahaan. Kepemilikan manajerial menjadi pihak yang menyatukan kepentingan manajer dan investor. Semakin besar jumlah kepemilikan saham manajemen, maka semakin baik tindakan manajer sebagai pemilik perusahaan dalam mengelola perusahaan. Apabila terdapat keputusan dan kebijakan yang diambil salah, maka manajemen juga akan menanggung konsekuensinya. Proporsi kepemilikan manajerial yang besar menjadikan manajemen akan cenderung berusaha dalam meningkatkan keuntungan perusahaan untuk kepentingan investor dan kepentingannya sendiri. Hal tersebut menjadi daya tarik untuk investor dalam menanamkan modalnya.

H16: Profitabilitas memediasi kepemilikan manajerial terhadap nilai perusahaan.

\section{METODE PENELITIAN}

Penelitian ini adalah penelitian kausalitas dengan metode kuantitatif. Sumber data menggunakan data sekunder dari Bursa Efek Indonesia. Populasi dalam penelitian ini adalah perusahaan pertambangan yang terdaftar di BEI tahun 2015-2018, dengan sampel 10 perusahaan dari 47 perusahaan yang ditentukan menggunakan teknik purposive sampling. Kriteria yang ditetapkan antara lain perusahaan yang menyajikan laporan tahunan secara lengkap periode 2015-2018 dan perusahaan yang melakukan pembagian dividen minimal 3 tahun dalam periode 2015-2018. Penelitian ini menggunakan path analysis dengan bantuan program IBM SPSS versi 25. Pengujian dilakukan melalui 2 tahap, pertama menggunakan uji statistik regresi yang digunakan untuk mengetahui ada tidaknya pengaruh antara variabel independen dengan variabel dependen. Kedua, menggunakan path analysis yang digunakan untuk mengetahui pengaruh langsung maupun tidak langsung antar variabel dalam model.

\section{HASIL DAN PEMBAHASAN}

\section{Uji Asumsi Klasik}

Tahap 1: $Y=\alpha+\beta_{1} X_{1}+\beta_{2} X_{2}+\beta_{3} X_{3}+\beta_{4} X_{4}+\beta_{5} X_{5}+\beta_{6} Z+e$

Berdasarkan penggunaan uji Kolmogorov-Smirnov pada uji normalitas, diperoleh nilai KS 0,190 dengan probabilitas $0,097>0,05$ sehingga dapat dikatakan normal. Hasil uji multikolonieritas masing-masing variabel independen menghasilkan nilai tolerance $>0,10$ dan nilai VIF $<10$, maka dapat dikatakan dalam model regresi tidak terjadi multikolonieritas. Penggunaan Run Test pada uji autokorelasi memperoleh hasil Asymp. Sig (2-tailed) sebesar 0,513>0,05 menunjukkan bahwa tidak terjadi gejala autokorelasi. Uji heteroskedastisitas menggunakan grafik scatterplot menunjukkan hasil titik-titik atau residual menyebar di atas dan di bawah 0 serta tidak membentuk suatu pola sehingga tidak terjadi heteroskedastisitas dalam model regresi.

Tahap 2: $Y=\alpha+\beta_{1} X_{1}+\beta_{2} X_{2}+\beta_{3} X_{3}+\beta_{4} X_{4}+\beta_{5} X_{5}+e$.

Hasil uji normalitas menggunakan uji Kolmogorov-Smirnov, diperoleh nilai KS sebesar 0,129 dengan probabilitas 0,479 berarti bahwa data residual berdistribusi normal. Uji multikolonieritas menunjukkan bahwa masing-masing variabel independen memiliki nilai tolerance $>0,10$ dan nilai VIF $<10$ sehingga tidak terjadi gejala multikolonieritas dalam model regresi. Uji autokorelasi menggunakan uji Durbin-Watson didapatkan hasil 1,7859<1,974<2,2141 $(\mathrm{du}<\mathrm{d}<4-\mathrm{du})$, hasil tersebut 
Emi Mei Astutik, Faktor-Faktor yang Memengaruhi Nilai Perusahaan dengan Profitabilitas sebagai Variabel Mediasi pada Sektor Pertambangan di BEI tahun 2015-2018

menunjukkan tidak terjadi autokorelasi. Hasil uji heteroskedastisitas mengunakan uji grafik scatterplot menunjukkan hasil titik-titik atau residual menyebar di atas dan di bawah 0 serta tidak membentuk suatu pola, sehingga dikatakan tidak terjadi heteroskedastisitas.

\section{Uji Hipotesis}

Tahap 1: $Y=\alpha+\beta_{1} X_{1}+\beta_{2} X_{2}+\beta_{3} X_{3}+\beta_{4} X_{4}+\beta_{5} X_{5}+\beta_{6} Z+e$

Tabel 1

UJI HIPOTESIS

\begin{tabular}{lllll}
\hline & B & T & Sig. & Keterangan \\
\hline Adjusted R Square & & & 0,579 & \\
Uji F & & & 0,000 & Berpengaruh \\
Uji t & & & & \\
(Constant) & 824,014 & 0.840 & 0,407 & \\
CSR & 2562,457 & 3,568 & 0,001 & Berpengaruh \\
Kebijakan Dividen & 700,921 & 4,344 & 0,000 & Berpengaruh \\
Umur Perusahaan & $-856,216$ & $-1,694$ & 0,100 & Tidak berpengaruh \\
Komisaris Independen & $-880,319$ & $-0,771$ & 0,446 & Tidak berpengaruh \\
Kepemilikan Manajerial & $-1783,698$ & $-0,973$ & 0,338 & Tidak berpengaruh \\
Profitabilitas & 2048,127 & 2,200 & 0,035 & Berpengaruh \\
\hline
\end{tabular}

Sumber: Output SPSS (2020)

Tabel 1 adalah hasil uji hipotesis yang meliputi uji koefisien determinasi, uji signifikan simultan (uji F), dan uji signifikan parameter individual (uji t). Diketahui bahwa nilai Adjusted $R^{2}$ sebesar 57,9\% yang berarti 57,9\% variabel nilai perusahaan dapat dijelaaskan oleh variabel independen dalam penelitian. Sedangkan sisanya $42,1 \%$ dijelaskan oleh variabel lain di luar variabel penelitian, seperti leverage, ukuran perusahaan, dan kualitas laba (Rahayu \& Sari, 2018). Uji F menghasilkan nilai F hitung $0,000<0,05$ artinya, secara bersama-sama variabel independen berpengaruh pada nilai perusahaan. Hasil dari uji t menunjukkan bahwa hipotesis diterima apabila nilai signifikansi $\leq 0,05$. Terdapat tiga hipotesis yang diterima yaitu tanggung jawab sosial perusahaan, kebijakan dividen, dan profitabilitas. Sedangkan hipotesis yang lain tidak dapat diterima karena tidak memenuhi kriteria.

Tahap 2: $Y=\alpha+\beta_{1} X_{1}+\beta_{2} X_{2}+\beta_{3} X_{3}+\beta_{4} X_{4}+\beta_{5} X_{5}+e$

Tabel 2

\section{UJI HIPOTESIS}

\begin{tabular}{lllll}
\hline & B & T & Sig. & Keterangan \\
\hline Adjusted R Square & & & 0,336 & \\
Uji F & & & 0,002 & Berpengaruh \\
Uji t & & & & \\
(Constant) & 0,350 & 2,052 & 0,48 & \\
CSR & $-0,319$ & $-2,652$ & 0,012 & Berpengaruh \\
Kebijakan Dividen & 0,010 & 0,349 & 0,729 & Tidak berpengaruh \\
Umur Perusahaan & 0,054 & 0,587 & 0,561 & Tidak berpengaruh \\
Komisaris Independen & $-0,541$ & $-2,865$ & 0,007 & Berpengaruh \\
Kepemilikan Manajerial & $-0,462$ & $-1,407$ & 0,169 & Tidak berpengaruh \\
\hline \multicolumn{2}{l}{ Sumber: Output SPSS (2020) } & & &
\end{tabular}

Hasil uji koefisien determinasi menunjukkan nilai Adjusted $R^{2}$ sebesar 33,6\%. Artinya 33,6\% nilai profitabilitas dijelaskan oleh variabel dependen dalam penelitian, sedangkan sisanya dipengaruhi variabel lain. Uji $\mathrm{F}$ menghasilkan nilai $\mathrm{F}$ hitung $0,002<0,05$ dan diartikan bahwa secara bersamasama variabel independen dapat berpengaruh pada profitabilitas. Hasil dari uji t menunjukkan bahwa 
terdapat dua hipotesis yang diterima yaitu tanggung jawab sosial perusahaan dan komisaris independen.

Ada tidaknya peran mediasi atau hubungan tidak langsung dalam penelitian ini dilakukan dengan menghitung rumus Sobel Test. Hasil perhitungan hubungan tidak langsung variabel tanggung jawab sosial perusahaan menunjukkan nilai t hitung -0,924; variabel kebijakan dividen 0,290; variabel umur perusahaan 0,467; variabel dewan komisaris independen -0,934; dan variabel kepemilikan manajerial $-0,788$. Hasil nilai t hitung semua variabel kurang dari t tabel pada tingkat signifikansi 0,05 yaitu sebesar 1,96, jadi koefisien mediasi tidak signifikan. Dengan kata lain, tidak ada pengaruh mediasi atau profitabilitas tidak dapat menjadi variabel mediasi dalam penelitian ini.

\section{Pengaruh Tanggung Jawab Sosial Perusahaan terhadap Nilai Perusahaan}

Pengujian statistik memberikan hasil bahwa tanggung jawab sosial perusahaan memiliki pengaruh dengan nilai perusahaan. Temuan tersebut sesuai dengan stakeholder theory yang menjelaskan pihak mana saja yang harus mendapat pertanggung jawaban dari perusahaan. Perusahaan harus menjaga hubungan terhadap stakeholdernya dengan mengakomodasi keinginan dan kebutuhannya yang dapat dilakukan dengan menerapkan tanggung jawab sosial sesuai dengan standar yang berlaku. Hal itu menunjukkan bahwa perusahaan tidak hanya mempertimbangkan kepentingan shareholder, namun juga mempertimbangkan kepentingan stakeholder atau masyarakat di sekitarnya. Tanggung jawab sosial yang dilakukan secara tepat akan menjadikan perusahaan semakin bernilai di mata investor (Rachmania, 2017). Interpretasi praktis hasil penelitian ini adalah perusahaaan dapat lebih berfokus pada tanggung jawab sosial perusahaan agar menjadi daya tarik untuk investor. Penelitian Bidhari et al. (2013) mendukung hasil temuan ini.

\section{Pengaruh Kebijakan Dividen terhadap Nilai Perusahaan}

Hasil penelitian diperoleh bahwa kebijakan dividen berpengaruh pada nilai perusahaan. Temuan ini sejalan dengan penelitian Rizqia et al. (2013). Mendukung bird in the hand theory yang dikembangkan oleh Myron Gordon dan John Lintner (1962-1963) bahwa harga saham perusahaan akan menjadi tinggi jika dividen yang dibagikan semakin besar sehingga mencerminkan peningkatan nilai perusahaan. Investor lebih memilih dividen karena memiliki sifat yang lebih pasti daripada capital gain, sehingga investor lebih tertarik dalam mempercayakan modalnya pada perusahaan yang membagikan dividen secara konsisten. Interpretasi praktis dari penelitian ini yaitu perusahaan dapat lebih konsisten atau bahkan menambah nilai pembayaran dividen setiap tahunnya dengan tujuan meningkatkan nilai perusahaan.

\section{Pengaruh Umur Perusahaan terhadap Nilai Perusahaan}

Hasil penelitian menunjukkan tidak ada pengaruh antara umur perusahaan pada nilai perusahaan. Temuan ini sejalan dengan penelitian Sucuahi \& Cambarihan (2016). Hal ini terjadi karena perusahaan yang baru cenderung lebih bersemangat dalam membangun usahanya dan lebih aktif melakukan promosi untuk memperkenalkan usahanya kepada publik. Sedangkan perusahaan yang telah lama berdiri cenderung lebih kaku dan usang yang menyebabkan perusahaan tersebut kurang dapat mengikuti pekembangan yang ada, sehingga perusahaan menjadi kurang diminati oleh investor. Hasil ini juga didukung dengan data penelitian, bahwa terdapat beberapa perusahaan yang berumur lama tidak memiliki nilai EPS yang tinggi, bahkan nilai EPS tinggi dimiliki oleh perusahaan yang baru berdiri. Sehingga umur perusahaan tidak dapat dijadikan sebagai patokan dalam mengukur subuah nilai perusahaan. Interpretasi teori hasil penelitian tidak sesuai dengan signalling theory yang menjelaskan bahwa semakin lama umur perusahaan dapat memberikan sinyal positif. Karena perusahaan memiliki lebih banyak pengalaman dalam mengelola perusahaan sehingga dapat mengatasi masalah yang terjadi dengan tepat (Yumiasih \& Isbanah, 2017). Interpretasi praktis hasil penelitian ini adalah perusahaan agar memerhatikan faktor lain dalam meningkatkan suatu nilai perusahaan. Hasil penelitian ini menjelaskan bahwa umur perusahaan tidak dapat menjadi faktor pengaruh untuk meningkatkan nilai perusahaan. 
Emi Mei Astutik, Faktor-Faktor yang Memengaruhi Nilai Perusahaan dengan Profitabilitas sebagai Variabel Mediasi pada Sektor Pertambangan di BEI tahun 2015-2018

\section{Pengaruh Dewan Komisaris Independen terhadap Nilai Perusahaan}

Hasil uji statistik menunjukkan bahwa tidak ada pengaruh dewan komisaris independen dengan nilai perusahaan. Penelitian Rachmania (2017) menjadi pendukung dalam penelitian ini. Tidak adanya pengaruh menunjukkan kurang efektifnya pengawasan yang dilakukan dalam perusahaan, sehingga tidak dapat meminimalisir tindakan kecurangan menajemen dalam pelaporan keuangan. Hal tersebut menyebabkan hilangnya kepercayaan investor dalam menanamkan modalnya pada perusahaan. Faktor lain juga disebabkan karena terdapat beberapa perusahaan yang memiliki anggota dewan komisaris independen dengan jumlah yang kurang, hal tersebut tidak sesuai dengan peraturan OJK No. 33/POJK.04/2014 yang mengatur mengenai anggota minimum dewan komisaris independen sebesar $30 \%$ dari jumlah anggota dewan komisaris. Interpretasi teori hasil penelitian tidak sesuai dengan agency theory yang menjelaskan bahwa jumlah anggota dewan komisaris independen dapat mengatasi masalah keagenan karena peran pengawasan yang dilakukan dapat dijalankan dengan baik apabila memiliki jumlah anggota yang memadai. Interpretasi praktis dari penelitian ini yaitu perusahaan agar lebih memerhatikan jumlah anggota dewan komisaris independen di dalam perusahaan.

\section{Pengaruh Kepemilikan Manajerial terhadap Nilai Perusahaan}

Hasil penelitian menunjukkan kepemilikan manajerial tidak memengaruhi nilai perusahaan. Penelitian Luthfiah \& Suherman (2018) dan Dewi \& Nugrahanti (2017) mendukung hasil ini. Tidak adanya pengaruh menunjukkan kepemilikan manajerial tidak mampu memonitor perusahaan untuk meningkatkan nilai bagi perusahaan. Faktor lain juga dipicu karena baik atau tidaknya nilai sebuah perusahaan tidak disebabkan oleh seberapa banyak kepemilikan saham manajemen namun bisa dipengaruhi oleh kemampuan pihak manajemen dalam mengelola perusahaannya. Hasil ini didukung dengan data, bahwa perusahaan yang menjadi sampel penelitian mempunyai rata-rata presentase kepemilikan saham sebesar $1 \%$. Minimnya persentase kepemilikan manajerial menyebabkan manajemen tidak bertindak sesuai dengan keinginan investor. Hasil penelitian ini berbeda dengan agency theory yang menjelaskan kepemilikan saham oleh manajemen dapat mengurangi masalah keagenan karena dapat menyelaraskan berbagai kepentingan dalam perusahaan. Interpretaasi praktis hasil penelitian ini adalah perusahaan agar menambah persentase kepemilikan saham oleh manajemen agar dapat meningkatkan nilai perusahaan.

\section{Pengaruh Profitabilitas terhadap Nilai Perusahaan}

Hasil uji hipotesis pengaruh profitabilitas terhadap nilai perusahaan menunjukkan nilai positif. Penelitian Zuhroh (2019) dan Susanti \& Restiana (2018) sejalan dengan penelitian ini. Adanya pengaruh profitabilitas menunjukkan bahwa meningkatnya profitabilitas mencerminkan kemampuan perusahaan dalam memperoleh laba tinggi. Laba yang tinggi menjadikan investor tertarik dalam membeli saham karena adanya prospek perusahaan yang baik. Sesuai dengan signalling theory yang menjelaskan bahwa profitabilitas akan menjadi sinyal mengenai prospek perusahaan berdasarkan tingkat laba yang terbentuk. Karena peningkatan laba akan menjadi acuan dalam pengambilan keputusan investasi oleh investor. Interpretasi praktis dari hasil penelitian ini yaitu perusahaan agar lebih berfokus pada profitabilitas perusahaan untuk menjadi sinyal positif bagi investor.

\section{Pengaruh Tanggung Jawab Sosial Perusahaan terhadap Profitabilitas}

Pengujian statistik memberikan hasil bahwa ada pengaruh tanggung jawab sosial perusahaan dengan profitabilitas. Hasil penelitian Rosdwianti et al. (2016) konsisten dengan hasil penelitian ini. Sejalan dengan stakeholder theory bahwa perusahaan harus bertanggung jawab kepada masyarakat yang memiliki kepentingan dengan usahanya. Karena peran penting dari tanggung jawab sosial perusahaan adalah menciptakan citra perusahaan. Investor lebih tertarik dengan perusahaan yang citranya baik, sehingga loyalitas konsumen terbentuk dan penjualan menjadi stabil. Tanggung jawab sosial yang semakin baik akan berdampak pada kelangsungan perusahaan dalam jangka panjang. Karena pengungkapan tanggung jawab sosial dalam laporan tahunan digunakan sebagai bahan pertimbangan oleh investor dalam berinvestasi. Interpretasi praktis dari hasil penelitian ini adalah perusahaan agar lebih meningkatkan kegiatan tanggung jawab sosial dengan tujuan dapat meningkatkan profitabilitas. 


\section{Pengaruh Kebijakan Dividen terhadap Profitabilitas}

Hasil uji hipotesis menunjukkan kebijakan dividen tidak memengaruhi profitabilitas perusahaan. Hasil tersebut sejalan dengan penelitian Henny (2017). Temuan ini menunjukkan bahwa kebijakan dividen tidak dapat dijadikan sebagai sarana untuk menginformasikan laba perusahaan, yang berarti perusahaan yang tidak membagikan dividen belum tentu profitabilitas yang diperoleh rendah dan sebaliknya. Selain itu, kebijakan dividen tidak digunakan oleh perusahaan sebagai sinyal mengenai kinerja keuangan untuk memeroleh laba perusahaan, melainkan hanya digunakan guna menarik aliran modal yang lebih besar dari investor. Sehingga tinggi atau rendahnya pembagian dividen tidak berpengaruh pada profitabilitas. Hasil penelitian ini juga didukung oleh data penelitian yang menunjukkan besarnya pembayaran dividen tidak menjadikan persentase ROA besar pula, bahkan ketika perusahaan menetapkan dividen lebih rendah berdampak pada peningkatan ROA perusahaan. Berbeda dengan bird in the hand theory yang menjelaskan bahwa pembagian dividen akan lebih menarik perhatian para investor dibandingkan dengan capital gain yang tidak pasti (Purnama, 2018). Interpretasi praktis dari hasil penelitian ini yaitu agar perusahaan menetapkan kebijakan pembayaran dividen yang lebih tinggi supaya diminati investor guna aliran modal perusahaan.

\section{Pengaruh Umur Perusahaan terhadap Profitabilitas}

Hasil uji hipotesis menunjukkan bahwa tidak terdapat pengaruh umur perusahaan dengan profitabilitas. Temuan tersebut konsisten dengan penelitian dari Arisadi et al. (2013). Sesuai dengan data penelitian ini, perusahaan yang berumur lama tidak menunjukkan persentase ROA yang paling tinggi. Sehingga umur perusahaan tidak dapat dijadikan sebagai standar reputasi sebuah perusahaan apabila dilihat dari perolehan laba. Hal ini terjadi karena perusahaan yang baru berdiri berhasil mendapatkan peluang baru untuk menghasilkan laba. Selain itu, perusahaan yang baru berdiri memungkinkan untuk mempunyai inovasi produk yang lebih baik. Interpretasi teori hasil penelitian tidak sesuai dengan signalling theory yang menjelaskan bahwa semakin lama umur perusahaan memberikan sinyal positif mengenai informasi laba perusahaan (Wibisana et al., 2018). Interpretasi praktis dari hasil penelitian ini ialah agar perusahaan memerhatikan faktor lain dalam meningkatkan nilai perusahaan, karena umur perusahaan tidak dapat menjadi faktor pengaruh untuk meningkatkan nilai perusahaan.

\section{Pengaruh Dewan Komisaris Independen terhadap Profitabiltas}

Pengujian statistik menunjukkan hasil bahwa ada pengaruh dewan komisaris independen terhadap profitabilitas. Sesuai dengan agency theory yang menjelaskan bahwa ukuran dewan komisaris independen dapat mengatasi masalah keagenan karena peran pengawasan dan pengendalian internal (Ramiyati, 2016). Jumlah anggota dewan komisaris independen yang sesuai menjadikan pengawasan lebih efektif dan obyektif untuk mengurangi tindakan manajemen yang hanya memikirkan kepentingan perusahaan serta mengurangi kecurangan yang menjadikan perusahaan rugi. Selain itu, manajemen akan selalu bertindak sesuai tujuan perusahaan yaitu menghasilkan keuntungan yang maksimal. Penelitian ini didukung oleh hasil penelitian Islami (2018) dan Putra (2015). Interpretasi praktis dari penelitian ini adalah perusahaan harus memerhatikan jumlah anggota dewan komisaris independen, karena dengan jumlah yang tepat dapat meningkatkan profitabilitas perusahaan.

\section{Pengaruh Kepemilikan Manajerial terhadap Profitabilitas}

Hasil uji hipotesis menunjukkan bahwa tidak terdapat pengaruh antara kepemilikan manajerial terhadap profitabilitas. Hasil ini konsisten dengan penelitian Kusumandari (2016) yang menyatakan kepemilikan manajerial tidak memengaruhi profitabilitas. Tidak adanya pengaruh kepemilikan manajerial terjadi karena proporsi kepemilikan saham manajemen dalam penelitian ini yang terlalu rendah mengakibatkan kinerja manajer kurang optimal, serta manajer sebagai pemilik saham minoritas tidak dapat berpartisipasi aktif dalam membuat keputusan pada perusahaan. Selain itu, proporsi saham yang dimiliki oleh pihak manajemen besarnya tetap, sehingga tidak dapat meminimalisir masalah keagenan dalam perusahaan. Hal tersebut tidak sesuai dengan agency theory yang menjelaskan bahwa kepemilikan saham yang dimiliki oleh pihak manajemen dapat mengurangi biaya keagenan (Ramiyati, 2016). Interpretasi praktis dari penelitian ini adalah agar perusahaan 
Emi Mei Astutik, Faktor-Faktor yang Memengaruhi Nilai Perusahaan dengan Profitabilitas sebagai Variabel Mediasi pada Sektor Pertambangan di BEI tahun 2015-2018

menambah persentase kepemilikan saham manajemen dengan tujuan dapat mengurangi masalah keagenan yang terjadi dalam perusahaan.

\section{Pengaruh Tanggung Jawab Sosial Perusahaan terhadap Nilai Perusahaan dengan Profitabilitas sebagai Variabel Mediasi}

Pengujian Sobel Test menunjukkan hasil bahwa profitabilitas tidak dapat memediasi pengaruh tanggung jawab sosial perusahaan dengan nilai perusahaan. Hasil ini didukung oleh data penelitian yang menunjukkan dengan tinggi rendahnya pengungkapan kegiatan tanggung jawab sosial perusahaan tidak mampu memengaruhi persentase ROA dan tidak dapat meningkatkan nilai EPS perusahaan. Hasil penelitian tidak sesuai dengan stakeholder theory yang menjelaskan perilaku etis perusahaan dalam melakukan tanggung jawab sosial dan lingkungan sekitarnya akan memberikan dampak yang positif dan akan tercermin pada keuntungan perusahaan dan peningkatan nilai perusahaan dalam jangka panjang (Zulaikhah, 2018). Dalam penelitian ini, kegiatan tanggung jawab sosial perusahaan tidak mampu memperkuat brand positioning, citra perusahaan, dan pangsa pasar, sehingga tidak dapat meningkatkan penjualan dan keuntungan perusahaan. Keuntungan perusahaan merupakan salah satu ukuran investor dalam menanamkan modalnya. Interpretasi praktis penelitian ini adalah perusahaan tidak perlu berfokus pada kegiatan tanggung jawab sosial perusahaan untuk peningkatan profitabilitas dan nilai perusahaan.

\section{Pengaruh Kebijakan Dividen terhadap Nilai Perusahaan dengan Profitabilitas sebagai Variabel Mediasi}

Pengujian Sobel Test menunjukkan hasil bahwa profitabilitas tidak dapat memediasi kebijakan dividen dengan nilai perusahaan. Sesuai dengan data penelitian ini, pembayaran dividen yang tinggi maupun rendah tidak menunjukkan dampak pada besar atau kecilnya nila ROA dan EPS perusahaan. Berbeda dengan bird in the hand theory yang menjelaskan bahwa investor tertarik dengan perusahaan yang membagikan dividen daripada capital gain, karena dividen lebih pasti dalam hal return dan memiliki risiko yang lebih kecil (Purnama, 2018). Dalam penelitian ini menunjukkan bahwa terdapat karakteristik sebagian investor yang lebih memilih tidak menerima dividen karena tarif pajaknya yang lebih tinggi daripada capital gain. Sehingga hal tersebut tidak lagi menjadi acuan investor dalam berinvestasi. Interpretasi praktis penelitian ini yaitu agar perusahaan tidak terlalu berfokus pada kebijakan dividen dalam meningkatkan profitabilitas dan nilai perusahaan.

\section{Pengaruh Umur Perusahaan terhadap Nilai Perusahaan dengan Profitabilitas sebagai Variabel Mediasi}

Hasil penelitian menunjukkan profitabilitas tidak dapat memediasi umur perusahaan terhadap nilai perusahaan. Hasil ini sejalan dengan data penelitian yang digunakan, semakin lama umur perusahaan tidak dapat memengaruhi nilai ROA sehingga tidak memberikan dampak pada EPS perusahaan. Interpretasi penelitian tidak sesuai dengan signalling theory yang menjelaskan bahwa perusahaan yang berumur lama mampu menghasilkan laba tinggi sehingga menjadi sinyal positif untuk investor dalam menanamkan modalnya. Dalam penelitian ini, tidak semua perusahaan yang berumur lama mengungkapkan aktivitas perusahaan secara lengkap dan memiliki profitabilitas tinggi, sehingga investor kurang tertarik untuk berinvestasi pada perusahaan tersebut. Interpretasi praktis hasil penelitian ini ialah agar perusahaan memerhatikan faktor lain dalam meningkatkan profitabiilitas dan nilai perusahaan (Ulfa, 2017) .

\section{Pengaruh Dewan Komisaris Independen terhadap Nilai Perusahaan dengan Profitabilitas sebagai Variabel Mediasi}

Penelitian ini menunjukkan hasil bahwa profitabilitas tidak dapat memediasi dewan komisaris independen terhadap nilai perusahaan. Hal ini didukung dengan data penelitian yang menunjukkan jumlah anggota dewan komisaris independen yang sesuai dengan peraturan Otoritas Jasa Keuangan tidak memberikan dampak pada profitabilitas dan nilai bagi perusahaan. Interpretasi penelitian tidak sejalan dengan agency theory yang menjelaskan bahwa dewan komisaris independen mampu mengatasi masalah keagenan karena peran pengawasan yang dilakukan lebih obyektif terhadap pengelolahan manajemen terkait profitabilitas (Ulfa, 2017). Dewan komisaris independen ialah anggota dewan komisaris yang berasal dari luar perusahaan, sehingga keterbatasan dalam 
pengetahuan perusahaan pasti dimiliki. Hal tersebut menjadikan tidak efektifnya pengawasan yang dilakukan pada pengelolahan manajemen mengenai kinerja perusahaan. Interpretasi praktis penelitian ini yaitu agar perusahaan memerhatikan jumlah anggota komisaris independen dan pengawasan yang dilakukan, karena dengan jumlah anggota dewan komisaris independen yang tepat dapat meningkatkan profitabilitas perusahaan dan nilai perusahaan.

\section{Pengaruh Kepemilikan Manajerial terhadap Nilai Perusahaan dengan Profitabilitas sebagai Variabel Mediasi}

Pengujian sobel test menghasilkan bahwa profitabilitas tidak mampu memediasi kepemilikan manajerial dengan nilai perusahaan. Penelitian yang dilakukan berbeda dengan agency theory yang menjelaskan bahwa kepemilikan saham manajemen dapat membuat manajer bertindak sesuai dengan keinginan investor dalam pencapaian laba (Ulfa, 2017). Dalam penelitian ini, kepemilikan saham manajemen tidak dapat meningkatkan perolehan laba perusahaan. Hal itu dikarenakan persentase kepemilikan saham manajemen sangatlah kecil. Sehingga masalah keagenan dapat terjadi, karena manajemen bukan termasuk pemilik saham mayoritas perusahaan. Interpretasi praktis hasil penelitian ini adalah agar perusahaan menambah persentase kepemilikan saham manajemen dalam perusahaan, sehingga manajemen dapat mengawasi perkembangan perusahaan sekaligus dapat turut serta dalam mengambil keputusan yang terbaik dari sisi investor dan kemajuan perusahaan.

\section{KESIMPULAN}

Simpulan yang dapat diambil berdasarkan penelitian yang dilakukan adalah tanggung jawab sosial perusahaan berpengaruh terhadap nilai perusahaan. Tanggung jawab sosial yang baik menjadikan perusahaan dipandang oleh investor semakin bernilai. Kebijakan dividen berpengaruh terhadap nilai perusahaan. Besar kecilnya dividen yang dibagikan akan memengaruhi investor dalam menilai perusahaan, karena investor cenderung tertarik pada perusahaan yang membagikan dividen dengan jumlah tinggi dalam berinvestasi. Umur perusahaan tidak berpengaruh terhadap nilai perusahaan. Umur perusahaan tidak dapat menjadi acuan oleh investor dalam menentukan perusahaan yang bernilai, karena umur perusahaan tidak dapat mencerminkan baik atau buruknya perusahaan. Dewan komisaris independen dan kepemilikan manajerial tidak berpengaruh terhadap nilai perusahaan. Karena good corporate governance tidak dapat menghambat terjadinya masalah keagenan dalam perusahaan, sehingga investor enggan untuk berinvestasi. Profitabilitas berpengaruh terhadap nilai perusahaan. Profitabilitas akan menjadi sinyal dari yang menggambarkan prospek perusahaan di masa mendatang, dan akan memengaruhi nilai perusahaan yang dicerminkan dari tingkat harga saham.

Bagi investor disarankan memertimbangkan segala informasi yang terdapat dalam laporan keuangan maupun laporan tahunan dengan tujuan dapat meminimalisir risiko dalam berinvestasi. Bagi Perusahaan agar lebih memerhatikan beberapa faktor dari penelitian ini yang berpengaruh terhadap peningkatan nilai perusahaan. Bagi peneliti selanjutnya, penelitian ini memiliki keterbatasan dalam variabel sehingga perlu ditambahkan beberapa variabel seperti leverage, ukuran perusahaan, dan kualitas laba.

\section{DAFTAR PUSTAKA}

Adi, A., Darminto, \& Atmanto, D. (2013). Pengaruh Return on Equity, Debt to Equity Ratio, Earning Per Share dan Book Value Per Share terhadap Harga Saham (Studi pada Perusahaan Consumer Goods Industry yang Terdaftar di BEI Periode 2008-2011). Jurnal Administrasi Bisnis, 4(2). https://doi.org/http://administrasibisnis.studentjournal.ub.ac.id

Andrian, J. (2012). Pengaruh Struktur Modal, Pertumbuhan Perusahaan, Capital Expenditure dan Insentif Manajer terhadap Nilai Perusahaan dengan Profitabilitas sebagai Variabel Intervening. Jurnal Magister Manajemen, 21(2). https://doi.org/https://doi.org/10.14710/jbs.21.2.18-45

Arisadi, Y. C., Djumahir, \& Djazuli, A. (2013). Pengaruh Ukuran Perusahaan , Umur Perusahaan , 
Emi Mei Astutik, Faktor-Faktor yang Memengaruhi Nilai Perusahaan dengan Profitabilitas sebagai Variabel Mediasi pada Sektor Pertambangan di BEI tahun 2015-2018

Current Ratio , Debt to Equity Ratio dan Fixed Asset to Total Asset Ratio terhadap Kinerja Keuangan pada Perusahaan Manufaktur di Bursa Efek Indonesia. Jurnal Aplikasi Manajemen, 11(4), 567-574.

Bidhari, S. C., Salim, U., \& Aisjah, S. (2013). Effect of Corporate Social Responsibility Information Disclosure on Financial Performance and Firm Value in Banking Industry Listed at Indonesia Stock Exchange. European Journal of Business and Management, 5(18), 39-47. https://doi.org/EJBM@iiste.org

Christine, Y., \& Ekasari, N. (2012). Pengaruh Corporate Social Responsibility terhadap Profitabilitas PT. Telkom Tbk sebagai Pemenang CSR Award 2008. Akrual Jurnal Akuntansi, 3(2), 196-208. https://doi.org/http://dx.doi.org/10.26740/jaj.v3n2.p196-208

Dewi, L. C., \& Nugrahanti, Y. W. (2017). Pengaruh Struktur Kepemilikan dan Dewan Komisaris Independen Terhadap Nilai Perusahaan (Studi pada Perusahaan Industri Barang Konsumsi di BEI Tahun 2011-2013). Journal of Business and Economics, 18(1), 64. https://doi.org/10.24002/kinerja.v18i1.518

Hakim, L. (2018). Pengaruh Kebijakan Dividen, Kepemilikan Manajerial, dan Intellectual Capital terhadap Nilai Perusahaan dengan Profitabilitas sebagai Variabel Intervening pada Perusahaan Manufaktur yang Terdaftar di Bursa Efek Indonesia. Skripsi Universitas Negeri Yogyakarta.

Harmono. (2017). Manajemen Keuangan Berbasis Balanced Scorecard Pendekatan Teori, Kasus, dan Riset Bisnis. Jakarta: Bumi Aksara.

Henny, L. A. (2017). Pengaruh Kebijakan Dividen, Leverage, dan Pertumbuhan Penjualan terhadap Profitabilitas pada Masa yang Akan Datang. Jurnal Akuntansi Unesa, 5(3), 1-25.

Islami, N. W. (2018). Pengaruh Corporate Governance terhadap Profitabilitas Perusahaan. Jurnal Ilmiah Bisnis Dan Ekonomi Asia, 12(1), 54-58. https://doi.org/https://doi.org/10.32812/jibeka.v12i1.15

Kusumandari, I. (2016). Pengaruh Dewan Komisaris, Dewan Direksi, Komite Audit, Kepemilikan Perusahaan Lain dan Kepemilikan Manajerial terhadap Profitabilitas Perbankan yang Terdaftar di Bursa Efek Indonesia Tahun 2011-2015. Jurnal Universitas Islam Indonesia, 45-46.

Luthfiah, A. A., \& Suherman, S. (2018). The Effects of Financial Performance toward Firm Value with Ownership Structure as Moderating Variable (The Study on Manufacturing Companies Listed in Indonesia Stock Exchange in the Period of 2012-2016). Journal of Business and Behavioural Entrepreneurship, 2(1), 18-27. https://doi.org/10.21009/jobbe.002.1.03

Mukhtaruddin, Relasari, \& Felmania, M. (2014). Good Corporate Governance Mechanism , Corporate Social Responsibility Disclosure on Firm Value: Empirical Study on Listed Company in Indonesia Stock Exchange. International Journal of Finance \& Accounting Studies, 2(1), 1-10. https://doi.org/10.7575/aiac.ijfas.v.2n.1p.1

Mukhtaruddin, Ubaidillah, Dewi, K., Hakiki, A., \& Nopriyanto. (2019). Good Corporate Governance, Corporate Social Responsibility, Firm Value, and Financial Performance as Moderating Variable. Indonesian Journal of Sustainability Accounting and Management, 3(1), 55. https://doi.org/10.28992/ijsam.v3i1.74

Nurwahidah, Husnan, L. H., \& AP, I. N. N. (2019). Pengaruh Kepemilikan Manajerial terhadap Nilai Perusahaan dengan Struktur Modal dan Profitabilitas sebagai Variabel Intervening pada Perusahaan Real Estate di Bursa Efek Indonesia. Jmm Unram - Master of Management Journal, 8(4). https://doi.org/10.29303/jmm.v8i4.460 
Pascareno, B. E., \& Siringoringo, H. (2016). The Effect of Financial Performance on Company's Value Moderated by Dividend Policy. Jurnal Ilmiah Ekonomi Bisnis, 370-377. https://doi.org/10.15414/isd2016.s5.07

Pratiwi, L. (2018). Pengaruh Kebijakan Utang dan Kebijakan Dividen terhadap Nilai Perusahaan dengan Profitabilitas sebagai Variabel Intervening. Journal Unper, 2(1), 21-36.

Purnama, H. (2018). Pengaruh Struktur Modal, Kebijakan Deviden dan Keputusan Investasi terhadap Profitabilitas (Studi Kasus Perusahaan Manufaktur yang Go Publik di Bursa Efek Indonesia) Periode 2012-2016. Jurnal Akuntansi \& Manajemen Akmenika, 15(2), 122-134. https://doi.org/http://repository.upy.ac.id/id/eprint/2075

Putra, B. P. D. (2015). Pengaruh Dewan Komisaris, Proporsi Komisaris Independen, terhadap Kinerja Perusahaan. Jurnal Manajemen Teori Dan Terapan, 8(2), 70-85. https://doi.org/http://dx.doi.org/10.20473/jmtt.v8i2.2724

Rachmania, D. (2017). Pengaruh Corporate Governance, Corporate Social Responsibility dan Komisaris Independen terhadap Nilai Perusahaan pada Industri Tekstil dan Garmen Periode 2011-2013. Competitive Jurnal Akuntansi Dan Keuangan, 1(1), 38. https://doi.org/10.31000/competitive.v1i1.107

Rahayu, F. D., \& Asandimitra, N. (2014). Pengaruh Ukuran Perusahaan, Leverage, Profitabilitas, Kebijakan Dividen dan Cash Holding terhadap Nilai Perusahaan pada Sektor Manufaktur. Jurnal Ilmu Manajemen (JIM), 2(2).

Rahayu, M., \& Sari, B. (2018). Faktor-Faktor yang Memengaruhi Nilai Perusahaan. Jurnal Sosial Dan Humaniora, 2(2), 69-76. https://doi.org/10.31603/bisnisekonomi.v16i1.2127

Raja, D. H. L. (2016). Pengaruh Dewan Komisaris, Komisaris Independen, Komite Audit terhadap Profitabilitas pada Perusahaan Sektor Property dan Real Estate yang Terdaftar di Bursa Efek Indonesia (BEI) Tahun 2009-2014. Jurnal Ilmu Manajemen, 4(2), 139-146. Retrieved from http://repository.uinjkt.ac.id/dspace/bitstream/123456789/27397/1/EGI FERDIANTO-FEB.pdf

Ramiyati. (2016). Pengaruh Dewan Komisaris, Komisaris Independen, Komite Audit, Kepemilikan Manajerial dan Kepemilikan Institutional terhadap Return on Asset (ROA) pada Perusahaan Food and Beverage yang Terdaftar di Bursa Efek Indonesia Periode Tahun 2013-2016. Jurnal Akuntansi, 1-12.

Rizqia, D. A., Aisjah, S., \& Sumiati. (2013). Effect of Managerial Ownership , Financial Leverage , Profitability, Firm Size, and Investment Opportunity on Dividend Policy and Firm Value. Research Journal of Finance and Accounting, 4(11), 120-130.

Rosdwianti, M. K., AR, M. D., \& Z.A, Z. (2016). Pengaruh Corporate Social Responsibility (CSR) terhadap Profitabilitas Perusahaan (Studi pada Perusahaan Sektor Industri Barang Konsumsi yang Terdaftar di Bursa Efek Indonesia Tahun 2010-2013). Jurnal Administrasi Bisnis (JAB), 38(2), 16-22. https://doi.org/10.21831/nominal.v4i2.8002

Rudangga, I. G. N. G., \& Sudiarta, G. M. (2016). Pengaruh Pertumbuhan Perusahaan dan Leverage terhadap Profitabilitas dan Nilai Perusahaan. E-Jurnal Manajemen Universitas Udayana, 5(7), 4394-4422.

Siahaan, F. O. p. (2013). The Effect of Good Corporate Governance Mechanism, Leverage, and Firm Size on Firm Value. GSTF Journal on Business Review (GBR), 4(3), 66-71. https://doi.org/10.5176/2010-4804 
Emi Mei Astutik, Faktor-Faktor yang Memengaruhi Nilai Perusahaan dengan Profitabilitas sebagai Variabel Mediasi pada Sektor Pertambangan di BEI tahun 2015-2018

Sucuahi, W., \& Cambarihan, J. M. (2016). Influence of Profitability to the Firm Value of Diversified Companies in the Philippines. Accounting and Finance Research, 5(2). https://doi.org/10.5430/afr.v5n2p149

Sudana, I. M. (2011). Teori \& Praktik Manajemen Keuangan Perusahaan. Jakarta: Erlangga.

Suryaningsih, I., Andini, R., \& Oemar, A. (2018). Pengaruh Kepemilikan Manajemen, Ukuran Dewan Komisaris \& Kebijakan Dividen terhadap Nilai Perusahaan dengan Corporate Social Responsibility sebagai Variabel Moderating. Jurnal Of Accounting, 4(4), 1-20.

Susanti, N., \& Restiana, N. G. (2018). What's the Best Factor to Determining Firm Value? Jurnal Keuangan Dan Perbankan, 22(2), 301-309. https://doi.org/10.26905/jkdp.v22i2.1529

Tandelilin, P. D. E. (2010). Portofolio dan Investasi: Teori dan Aplikasi. Yogyakarta: Kanisius.

Tribun News. (2015). Retrieved March 22, 2020, from https://www.tribunnews.com/bisnis/2015/12/27/saham-sektor-pertambangan-tergerus-pada-2015

Ulfa, B. U. (2017). Pengaruh Good Corporate Governance dan Karakteristik Perusahaan terhadap Nilai Perusahaan dengan Profitabilitas sebagai Variabel Intervening. Skripsi UIN Maulana Ibrahim Malang.

Utomo, N. A. (2016). Faktor-Faktor yang Mempengaruhi Nilai Perusahaan pada Perusahaan Indeks LQ45 di Bursa Efek Indonesia. Dinamika Akuntansi, Keuangan Dan Perbankan, 5(1), 82-94. https://doi.org/1979-4878

Wibisana, I. A., Mardani, R. M., \& Wahono, B. (2018). Pengaruh Manajemen Modal Kerja, Umur Perusahaan dan Ukuran Perusahaan terhadap Profitabilitas (Studi pada Perusahaan Manufaktur yang Terdaftar di Bursa Efek Indonesia Periode 2015-2017). Jurnal Riset Manajemen, 7(5), 2542 .

Yumiasih, L., \& Isbanah, Y. (2017). Pengaruh Kompensasi, Ukuran Perusahaan, Usia Perusahaan, dan Leverage terhadap Nilai Perusahaan Sektor Pertanian yang Terdaftar di BEI Periode 20122015. Jurnal Ilmu Manajemen, 5(3), 1-9.

Zuhroh, I. (2019). The Effects of Liquidity, Firm Size, and Profitability on the Firm Value with Mediating Leverage. KnE Social Sciences, Vol. 3, p. 203. https://doi.org/10.18502/kss.v3i13.4206 